\section{CPD CHAMPION RECEIVES AWARD}

Professor Andrew Eder is this year's recipient of a UCL Provost's Teaching Award in the category of Supporting Student Learning.

Professor Eder has been associated with the UCL Eastman Dental Institute since 1989; following a number of teaching and directorship roles, he was appointed Associated Dean for Continuing Education in 2008.

The Provost's Teaching Awards celebrate leadership in teaching and learning across UCL's eight faculties, and demonstrate the Institute's commitment to the promotion of research-led training.

Among his achievements, Professor Eder has championed the growth of web-based learning, including the establishment of journal-based CPD for dentists.

A ceremony to celebrate the recipients' achievements took place on 8 July 2010.

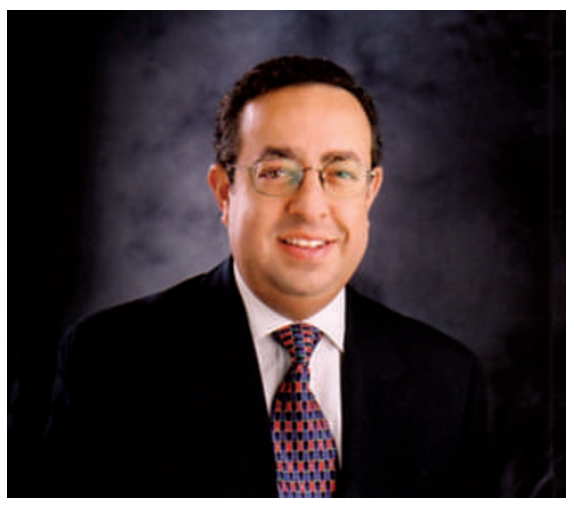

\section{PROFESSION CONFOUNDED BY UNREALISTIC PAY AWARD}

The Northern Ireland Department of Health, Social Services and Public Safety's (DHSSPS's) confirmation of a pay award for 2010-2011 which produces no increase to net earnings for high street dentists and minimal uplift to practice expenses has confounded the dental profession. Salaried dentists working in Trusts are to receive a one percent pay increase.

Claudette Christie, BDA Director for Northern Ireland, said: 'The basis of this announcement is simply unrealistic. Northern Ireland's dentists have provided health service care to 900,000 people in the communities they serve this year. Salaried dentists working in Trusts treat some of the most vulnerable patients in the community. For dentists to fulfil their responsibilities to these patients it is important they are properly supported.

'The idea that practitioners can reduce practice running costs does not reflect the reality of a situation where practices face sharply escalating costs... As clinicians, employing highly skilled staff, [dentists are] aware of the absolute importance of maintaining standards for their patients and investing in the care they provide.'

Health Minister Michael McGimpsey announced the pay award, which arose from the recommendations of the Doctors' and Dentists' Review Body (DDRB).

'I want to continue to improve services for our patients and clients,' said McGimpsey. 'My department will continue to work with the British Medical Association (BMA) and the British Dental Association (BDA) to focus resources on local priorities.'

\title{
ORTHODONTIC CLINICAL GUIDELINES UPDATED
}

Three of the national Orthodontic Clinical Guidelines have been updated by the Clinical Effectiveness Committee of the Faculty of Dental Surgery (England). They are on the topics of Management of the palatally ectopic maxillary canine; Management of the unerupted maxillary incisors; and Guidelines for first permanent molar extractions in children.
The guidelines are intended to assist dentists in making decisions about the appropriate management of these particular conditions thereby providing their patients with best practice.

The updated guidelines can be downloaded free of charge from the Royal College of Surgeons of England website: www.rcseng.ac.uk/fds/publicationsclinical-guidelines/clinical_guidelines.

\section{RCS CELEBRATES LIFE OF PIONEER TOMES}

A new exhibition at the Royal College of Surgeons (RCS) celebrates the life, career and achievements of one of Britain's most influential dentists, Sir John Tomes.

Sir John Tomes: Victorian Dental Pioneer opened at the Hunterian Museum on 22 June and will run until 25 September. Dental artefacts dating back to the nineteenth century will be on display, including some of Tomes' original instruments, texts and drawings. Also on show will be a variety of skulls and teeth that Tomes used and prepared to educate students.

'It's wonderful to welcome this exhibition as the RCS commemorates 150 years of the Licence in Dental Surgery,' said Professor Derrick Willmott, Faculty of Dental Surgery Dean. 'Tomes was key in lobbying for the creation of qualification.'

Key exhibits include draft pencil sketches of each tooth type by Sir John Tomes, examples from Tomes' microscope slide collection and Tomes' BDA chairman medal.

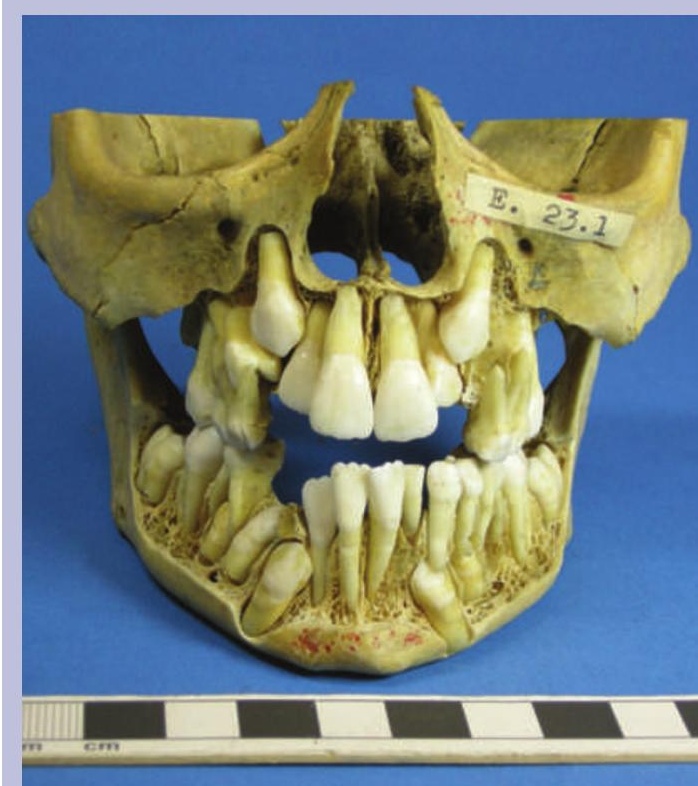

Portions of the maxillae and mandible of a child aged seven years three months showing the developing dentition. The alveolar bone has been removed to expose the roots of the deciduous teeth and the developing permanent teeth within the jaw. (Donated to RCS by Tomes) 